\title{
ZHODNOTENIE FINANČNEJ SITUÁCIE ČESKEJ PODNIKATELSKEJ POJIŠŤOVNY, A. S., VIENNA INSURANCE GROUP V OBDOBÍ 2003 - 2010
}

\author{
Miroslav Lukáč, Eva Kafková
}

Kl’účové slová:

predpísané poistné, solventnost', likvidita, rentabilita, investície, technické rezervy, investičná činnost'

\section{Key words:}

premium written, solvency, liquidity, rentability, investments, technical reserves, investment activities

\begin{abstract}
Abstrakt
Článok je zameraný na zhodnotenie finančnej situácie Českej podnikatelskej pojišt'ovny, a. s., Vienna Insurance Group, ktorá v posledných rokoch predstavuje ôsmeho najväčšieho poist'ovatel'a na území Českej republiky. Zhodnotenie bolo realizované prostredníctvom vybraných finančných ukazovatel'ov: predpísaného poistného, výsledku hospodárenia, analýzy súvahy a výkazu ziskov a strát, likvidity, rentability a analýzy investičnej činnosti. Dosiahnuté výsledky pomerových indikátorov Českej podnikatelskej pojišt'ovny, a. s. za obdobie 2003 - 2010 sme porovnávali s hodnotami celého poistného odvetvia v ČR za rok 2010 a zároveň s odporúčanými hodnotami ratingovej agentúry Standard \& Poor's.
\end{abstract}

\begin{abstract}
This article is focused on evaluation of financial situation of Česká podnikatelská pojišt'ovna, a. s., Vienna Insurance Group, which represents the eighth biggest insurance company in Czech Republic in the last years. The evaluation was realized through the chosen financial indicators: insurance written premium, trading income, analysis reporting income and loss, liquidity, rentability and investment activity analysis. We compared reached results of ratio indicators of Česká podnikatelská pojišt'ovna, a. s. from 2003 to 2010 with results of all Czech insurance industry in 2010 and concurrently with recommended attributes from rating agency Standard \& Poor's.
\end{abstract}

\section{Úvod}

Pôvod problematiky splácania záväzkov sa datuje do obdobia samotného vzniku dlhov. Vzhl'adom na ich neustále rastúci význam v trhovej ekonomike rastie aj dôležitost' hodnotenia bonity dlžníkov. Toto ohodnotenie rizika, že subjekt nebude schopný plnit' svoje záväzky, nazývame rating. V súčasnosti ho vypracovávajú predovšetkým špecializované spoločnosti, tzv. ratingové agentúry. Tie však zlyhali v poskytovaní objektívnych informácií, čím sa im pripisuje značný podiel na vzniku finančnej krízy v USA, ktorá sa postupne transformovala na globálnu hospodársku krízu. Z tohto dôvodu sa znížila dôveryhodnost' ratingových agentúr a mnohé vel'ké spoločnosti pristúpili k hodnoteniu finančného zdravia z prostriedkov vlastných zdrojov. Na poistnom trhu však na strane veritel'a vystupujú všetci poistení, čiže klienti poist'ovacích subjektov, ktorí väčšinou nedisponujú takýmito možnost’ami. Práve pre nich by mali byt' informácie o finančnej situácií jednotlivých poist’ovní jedným z najdôležitejších faktorov pri rozhodovaní o výbere poist'ovne. Českej podnikatelskej pojišt'ovně, a. s. síce 
patrí až ôsma pozícia na českom poistnom trhu, ale v roku 2005 sa stala súčast'ou rakúskeho poist'ovacieho koncernu Vienna Insurance Group a v súčasnosti patrí medzi najprogresívnejšie poist'ovne pôsobiace na území ČR.

\section{Ciel' a metodika}

Ciel'om príspevku je zhodnotit' finančnú situáciu Českej podnikatelskej pojišt'ovny, a. s., Vienna Insurance Group na základe vypracovanej finančnej analýzy poist’ovatel'a za roky 2003 až 2010. Pri vykonaní finančnej analýzy sme použili metodiku hodnotenia poist'ovní renomovanej ratingovej agentúry Standard \& Poor's doplnenú o d'alšie ukazovatele. Dosiahnuté výsledky pomerových ukazovatel'ov spoločnosti sme porovnávali s výsledkami celého poistného odvetvia v ČR za rok 2010 (ČR 10) a zároveň s odporúčanými hodnotami ratingovej agentúry (posledný stĺpec s popisom „S \& P“). Finančná analýza poist'ovne je rozdelená do piatich základných okruhov:

- výkonové ukazovatele,

- analýza súvahy a výkazu ziskov a strát,

- analýza likvidity,

- analýza rentability a

- analýza investičnej činnosti.

Výkonové ukazovatele sme popísali prostredníctvom predpísaného poistného, jeho medziročných nárastov a výsledku hospodárenia.

Analýza súvahy a výkazu ziskov a strát zahŕňa základné pomerové ukazovatele týkajúce sa analýzy dvoch najdôležitejších finančných podnikových výkazov a to súvahy a výkazu ziskov a strát. Táto čast' obsahuje predovšetkým špecifické ukazovatele používané pri hodnotení komerčných poist'ovní.

Likvidita aj solventnost' charakterizujú a kvantifikujú úroveň plnenia záväzkov. Solventnost' sa viaže $\mathrm{k}$ dlhšiemu obdobiu a likvidita sa chápe ako momentálna schopnost' plnit' záväzky vyplývajúce z uzatvorených a platných poistných zmlúv. Z hl’adiska analýzy likvidity poist'ovne však sledujeme predovšetkým likviditu dlhodobejšieho charakteru, pretože krátkodobé záväzky (aj vo vel'kom objeme) vyplývajúce zo vzniku poistných udalostí môžu vznikat' vo vel'mi krátkom časovom období. Poist'ovňa tak musí mat' k dispozícii vel'ký objem najlikvidnejších aktív v každom momente bez ohl'adu na výšku krátkodobých záväzkov. Na analýzu likvidity sme použili nasledovné ukazovatele: pomer technických rezerv (TR) k likvidným prostriedkom, podiel záväzkov na likvidných prostriedkoch a solvency ratio. Pojem likvidné prostriedky nie je presne definovaný a sleduje sa ich vzt'ah k celkovým záväzkom a celkovým rezervám. Z tohto dôvodu likvidné prostriedky pre potreby tejto práce zahŕňajú aj dlhodobo likvidné prostriedky, ako napr. dlhopisy, dlhodobé pohl'adávky a termínované vklady.

Ukazovatele rentability vyjadrujú efektívnost' podnikania, čiže mieru zhodnotenia podnikového úsilia. Pre túto skupinu indikátorov platí, že čím je hodnota vyššia, tým bola vyššia efektívnost’ podnikania.

V rámci analýzy investičnej činnosti sledujeme vývoj celkových investícií a štruktúru finančných aktív, do ktorých poist'ovňa umiestňuje dočasne vol'né peňažné prostriedky kumulované v technických rezervách. 


\section{Charakteristika Českej podnikatelskej pojišt’ovny, a. s. Vienna Insurance Group}

Česká podnikatelská pojišt'ovna, a. s., Vienna Insurance Group (d’alej ČPP) bola založená 22. júna 1995. Poist'ovacia činnost' bola zahájená 6. novembra, ked' spoločnost' Česká podnikatelská pojištovna, a. s. bola zapísaná do obchodného registra. V júli 2005 sa jediným akcionárom ČPP stala Kooperativa, pojišt'ovna, a. s., ktorá je dcérskou spoločnost'ou WIENER STÄDTISCHE Versicherung AG VIENNA INSURANCE GROUP. Týmto sa poist'ovňa stala členom rakúskeho poist'ovacieho koncernu Vienna Insurance Group (VIG).

ČPP je univerzálna poist’ovňa, ktorá ponúka svojím klientom produkty a komplexné poistné riešenia v oblasti životného i neživotného poistenia. Tri štvrtiny poistného však pripadajú na neživotné poistenie (NŽP) a t'ažisko poistného portfólia tvorí poistenie motorových vozidiel. S počtom 970000 poistených vozidiel je ČPP tretím najväčším poist'ovatel'om povinného ručenia v ČR. Poist’ovňa spravuje takmer 1,4 mil. zmlúv svojich klientov a každý mesiac uzatvára približne 45 tisíc nových poistných zmlúv. Spoločnost' pôsobí na celom území ČR prostredníctvom 10 oblastných riaditel'stiev, 80 pobočiek a viac ako 300 poist'ovacích kancelárií a obchodných miest sprostredkovatel'ov. Nárast predpísaného poistného poist'ovne v posledných ôsmych rokoch prevažne prevyšuje nárast celého českého poistného trhu, čím ČPP zvyšuje svoj podiel na trhu.

\section{Analýza základných ukazovatel'ov}

V d'alších častiach postupne analyzujeme vybrané finančné ukazovatele v ČPP za roky 2003 až 2010, ale v priložených tabul'kách uvádzame len výsledky za roky 2005 až 2010. Tieto indikátory sme rozdelili do piatich oblastí: výkonové ukazovatele, analýza súvahy a výkazu ziskov a strát, ukazovatele likvidity, ukazovatele rentability a analýza investičnej činnosti.

\subsection{Výkonové ukazovatele}

\section{Predpísané poistné}

Hrubé predpísané poistné v roku 2010 dosiahlo 6372 mil. Kč, čo predstavovalo medziročný nárast $3 \%$, zatial' čo nárast trhu bol $8,1 \%$. Na celkovom raste predpisu sa podiel'al segment životného poistenia (ŽP), kde trhový nárast činil 19,2\%, zatial’ čo ČPP vykázala 10,4\%. Predpísané poistné v ŽP predstavovalo 1853 mil. Kč a tvorilo tak 29,1\% celkového predpisu. Ročný nárast $0,2 \% \mathrm{v}$ segmente NŽP znamenal, že poistné ČPP v tomto segmente na konci roku 2010 činilo 4519 mil. Kč. Vývoj predpísaného poistného v ČPP za obdobie 2005 až 2010 zobrazuje Tabul'ka č. 1.

Tabul'ka č. 1 Vývoj predpísaného poistného

\begin{tabular}{|l|c|r|r|r|r|r|r|}
\hline \multicolumn{1}{|c|}{ Ukazovatel' } & M. j. & \multicolumn{1}{c|}{$\mathbf{2 0 0 5}$} & \multicolumn{1}{c|}{$\mathbf{2 0 0 6}$} & $\mathbf{2 0 0 7}$ & $\mathbf{2 0 0 8}$ & $\mathbf{2 0 0 9}$ & \multicolumn{1}{c|}{$\mathbf{2 0 1 0}$} \\
\hline Predpísané poistné spolu & mil. Kč & 4011 & 4345 & 4751 & 5425 & 6186 & 6372 \\
\hline Predpísané poistné v ŽP & mil. Kč & 889 & 1083 & 1215 & 1400 & 1678 & 1853 \\
\hline Predpísané poistné v NŽP & mil. Kč & 3122 & 3262 & 3536 & 4025 & 4508 & 4519 \\
\hline Celkový nárast PP & $\%$ & 8,23 & 8,33 & 9,34 & 14,19 & 14,03 & 3,01 \\
\hline Ročný nárast PP v ŽP & $\%$ & 10,71 & 21,82 & 12,19 & 15,23 & 19,86 & 10,43 \\
\hline Ročný nárast PP v NŽP & $\%$ & 7,54 & 4,48 & 8,40 & 13,83 & 12,00 & 0,24 \\
\hline
\end{tabular}

Zdroj: Výročné správy ČAP za roky 2008 a 2010 a vlastné výpočty.

ČPP v sledovanom období zaznamenala celkovo vyššie nárasty predpísaného poistného ako celý český trh, výnimku však tvorí segment ŽP v rokoch 2007 a 2010. Nadpriemerný rast 
predpísaného poistného sa prejavoval aj v rastúcom trhovom podiele najmä v segmente NŽP, ale i celkovo. Nižší nárast v ŽP v roku 2010 spôsobil pokles podielu na trhu nielen v danom segmente, ale aj celkovo. ČPP tak na konci roku 2010 bola piatym najväčším poist'ovatel'om v ČR v oblasti NŽP s trhovým podielom 5,37\%. V ŽP jej s podielom 2,58 \% patrí jedenáste miesto a celkovo predstavuje ôsmu najväčšiu poist'ovňu na českom trhu s podielom $4,08 \%$.

Výsledok hospodárenia

Vo všetkých sledovaných rokoch ČPP dosahovala zisk a od roku 2005 vykazuje rastúcu tendenciu. Práve v tomto roku sa poist'ovňa zaradila do skupiny VIG a začalo rožsirovanie pola pôsobnosti. To spočívalo v budovaní vlastnej obchodnej siete i zvýšení spolupráce so sprostredkovatel'mi. Výsledok sa dostavil už v nasledujúcom roku, ked' poist'ovňa vykázala medziročný nárast zisku $866 \%$ a čistý zisk predstavoval 106 mil. Kč. V roku 2010 sa zisk zvýšil až na takmer 389 mil. Kč. Vývoj čistého zisku ČPP v období rokov 2003 až 2010 vyjadruje Graf č. 1 .

Graf č. 1 Vývoj čistého zisku

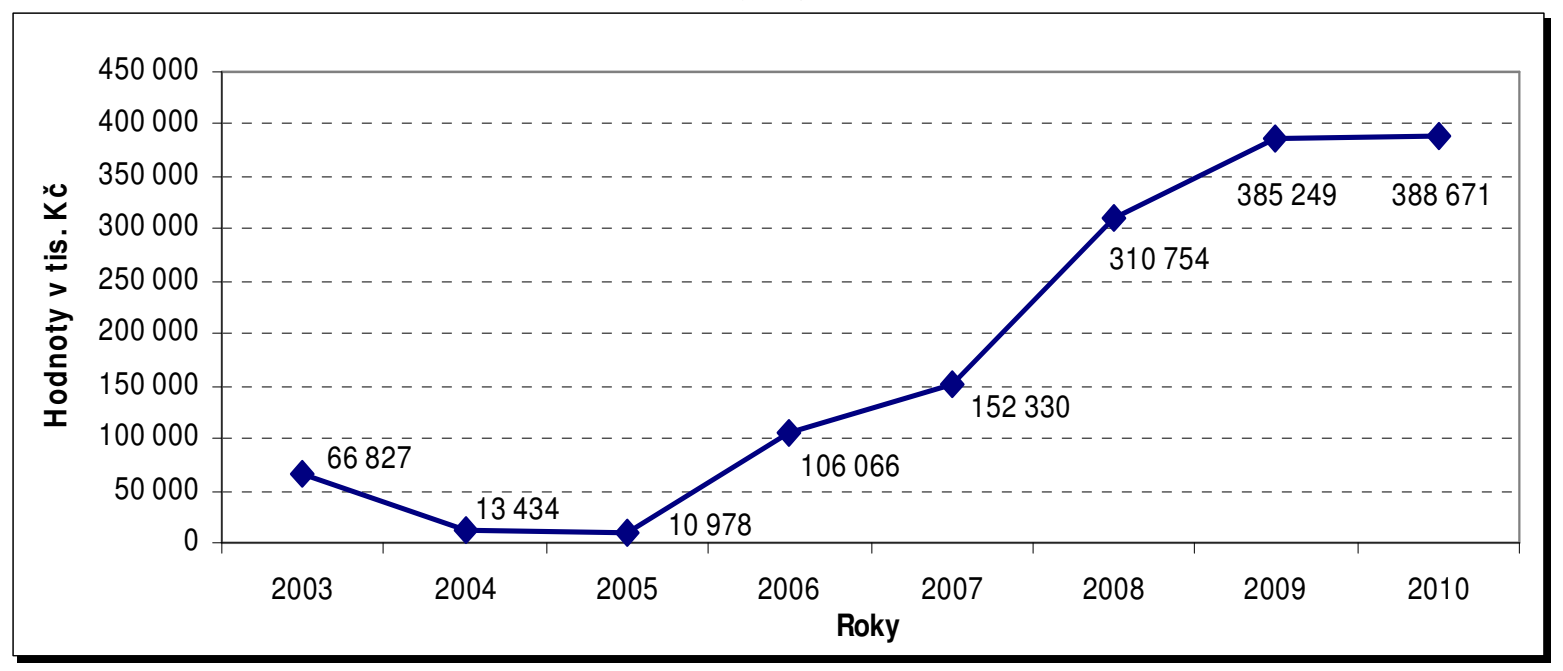

Zdroj: Výročné správy ČPP za roky 2003 - 2010.

\subsection{Analýza súvahy a výkazu ziskov a strát}

Vývoj ukazovatel'ov v ČPP za roky 2005 až 2010 a českého poistného trhu ako odvetvia (zastúpeného členmi Českej asociácie poist'ovní - ČAP) za rok 2010 zobrazuje Tabul'ka č. 2.

Tabul'ka č. 2 Vývoj ukazovatel’ov súvahy a výkazu ziskov a strát

\begin{tabular}{|l|r|c|r|r|c|r|r|c|}
\hline Ukazovatele (v \%) & $\mathbf{2 0 0 5}$ & $\mathbf{2 0 0 6}$ & $\mathbf{2 0 0 7}$ & $\mathbf{2 0 0 8}$ & $\mathbf{2 0 0 9}$ & $\mathbf{2 0 1 0}$ & ČR 10 & S \& P \\
\hline Asset leverage & 109,1 & 132,8 & 143,2 & 149,2 & 155,1 & 190,9 & 297,7 & čím vyšší \\
\hline Reserve ratio & 97,3 & 117,6 & 129,1 & 133,4 & 136,5 & 163,5 & 245,3 & $100-150$ \\
\hline Solvency ratio & 20,4 & 23,0 & 21,7 & 24,2 & 29,1 & 38,5 & 61,1 & $30-50$ \\
\hline Technical coverage ratio & 117,8 & 140,6 & 150,8 & 157,5 & 165,5 & 202,1 & 306,4 & $>150$ \\
\hline Investovanie aktív & 83,1 & 85,7 & 87,3 & 86,5 & 85,1 & 83,6 & 89,6 & neuvádza \\
\hline Investovanie TR & 113,6 & 112,6 & 109,5 & 113,9 & 113,4 & 119,9 & 120,9 & $>100$ \\
\hline Podiel TR na VI & 470,9 & 546,4 & 644,2 & 490,7 & 452,9 & 400,3 & 394,1 & $<350$ \\
\hline Uk. samofinancovania & 15,5 & 13,9 & 12,4 & 15,5 & 16,6 & 17,4 & 18,8 & neuvádza \\
\hline
\end{tabular}

Zdroj: Výročné správy ČPP za roky 2005 - 2010; Výročná správa ČAP za rok 2010 a vlastné výpočty. 
Ukazovatel' asset leverage má pozitívny rastúci trend v sledovanom období. Zobrazuje podiel investícií na netto zaslúženom poistnom a jeho hodnota by mala byt' čo najvyššia. Dosiahnutý výsledok $191 \%$ v roku 2010 poukazuje na dôležité postavenie investičnej činnosti vzhl'adom na poist'ovaciu, ale nie až natol'ko ako u celého českého poistného trhu (298\%). Investície sú však v súlade rezervami, ktorých tvorbu vyjadruje d’alší ukazovatel'.

Reserve ratio predstavuje pomer technických rezerv k netto zaslúženému poistnému. Ukazovatel' vyjadruje mieru vytvárania technických rezerv a mal by sa pohybovat' v intervale 100 až $150 \%$. Hodnoty ČPP majú rastúci trend, v prvých troch sledovaných rokoch vytvárala poist'ovňa malý objem a v roku 2010 až privel'ký objem TR. Technické rezervy boli vytvorené v správnom objeme len v rokoch 2006 až 2009. Technické rezervy celého českého odvetvia sú trvalo tvorené až v neprimerane vel'kom objeme, pričom v roku 2010 dosiahol český trh hodnotu $245 \%$.

Ukazovatel' solvency ratio určuje všeobecne optimálnu výšku vlastných zdrojov poist'ovne vzhl'adom na objem poist'ovacej činnosti. Ratingová agentúra S \& P odporúča hodnoty 30 až $50 \%$. S výnimkou roku 2007 vykazuje ČPP rastúci trend, ale len v poslednom sledovanom roku dosiahol poist'ovatel' hodnotu $(38,5 \%)$ z odporúčaného intervalu. Český trh vykázal v posledných štyroch rokoch hodnoty s rastúcou tendenciou nad hornou odporúčanou hranicou a v roku 2010 dosiahol úroveň 61,1 \%. Poist'ovňa ČPP mala predovšetkým v minulosti problémy v oblasti solventnosti, ale situácia sa postupne zlepšuje.

Indikátor technical coverage ratio je súhrnným ukazovatel'om predchádzajúcich dvoch. Hodnoty v ČPP majú pozitívny rastúci trend, ale dolnú odporúčanú hranicu (150\%) prekonala poist’ovňa až v posledných štyroch rokoch (151 až $202 \%)$. Do budúcnosti tak má pozitívne vyhliadky, hoci v predchádzajúcich rokoch nemala dostatok zdrojov na krytie záväzkov z poist'ovacej činnosti. Celé odvetvie dosiahlo v roku 2010 hodnotu $306 \%$.

Investovanie peňažných prostriedkov umiestnených technických rezerv vyjadruje, kol'ko percent aktív má investičný charakter. Poist'ovňa dosahovala rastúcu tendenciu do roku 2007, kedy bolo investovaných vyše $87 \%$ aktív, čo predstavovalo vel'mi blízku hodnotu i celému odvetviu (89 \%). Od uvedeného roku však hodnota klesá až na necelých 84 \% v roku 2010, zatial' čo český trh vykázal takmer $90 \%$.

V ukazovateli investovanie technických rezerv poist'ovňa len v roku 2003 nedosahuje dolnú odporučenú hranicu $100 \%$. Vo všetkých d’alších rokoch už kritérium ratingovej agentúry splña. ČPP tak investuje primeraný objem technických rezerv, ale zaostáva vo finančnom umiestnení vlastných zdrojov, čo vyplýva z ich malého objemu. Poist'ovňa v roku 2010 vykázala hodnotu $120 \%$ a český poistný trh $121 \%$.

Podiel TR na VI v poist'ovni v celom sledovanom období presahuje hornú odporučenú hranicu $(350 \%)$ a do roku 2007 mala negatívny rastúci charakter (644\%). Celé odvetvie dosiahlo tiež vysokú hodnotu $470 \%$. Od uvedeného roku dochádza k postupnému zlepšovaniu situácie v prípade poist'ovne (až na $400 \%$ v roku 2010) i celého poistného odvetvia (394\%). V prípade trhu je dôvodom neprimerane vel'ký objem vytvorených TR, čo predstavuje menší problém ako u ČPP. Poist'ovňa najmä v predchádzajúcich rokoch disponovala malým objemom vlastného kapitálu, čo ohrozovalo jej solventnost'. V poslednom sledovanom roku je už objem vlastného imania dostačujúci a dôvodom vysokej hodnoty ukazovatel'a je taktiež väčší objem vytvorených technických rezerv. 
Ukazovatel' samofinancovania úzko súvisí s predchádzajúcim indikátorom i s ukazovatel'om solvency ratio. Od roku 2007 sa zvyšuje podiel vlastného kapitálu a v roku 2010 predstavuje vlastné imanie v ČPP 17,4\% zo zdrojov. Napriek tomu nedosahuje v posledných štyroch rokoch ani úroveň celého odvetvia $(18,8 \%$ v roku 2010) a na trhu sa radí k rizikovejším poist'ovniam, ktoré intenzívnejšie využívajú výhody finančného leverage (rizika) v podobe nižších priemerných nákladov kapitálu.

\subsection{Analýza likvidity}

Vývoj ukazovatel'ov likvidity v poist'ovni za roky 2005 až 2010 a hodnoty českého poistného odvetvia (zastúpeného členmi ČAP) v roku 2010 zobrazuje Tabul'ka č. 3. Odporúčania ratingovej agentúry Standard \& Poor's sú uvedené v poslednom stlpci.

Tabul'ka č. 3 Vývoj ukazovatel'ov likvidity

\begin{tabular}{|l|r|r|r|r|r|r|r|c|}
\hline Ukazovatele (v \%) & $\mathbf{2 0 0 5}$ & $\mathbf{2 0 0 6}$ & $\mathbf{2 0 0 7}$ & $\mathbf{2 0 0 8}$ & $\mathbf{2 0 0 9}$ & $\mathbf{2 0 1 0}$ & ČR 10 & S \& P \\
\hline TR/Likvidné prostriedky & 77,8 & 79,7 & 83,3 & 80,2 & 80,6 & 75,3 & 76,5 & $<100$ \\
\hline Záväzky/Likvid. prostriedky & 6,6 & 5,4 & 3,6 & 5,4 & 4,1 & 4,0 & 5,6 & čím nižší \\
\hline Solvency ratio & 20,4 & 23,0 & 21,7 & 24,2 & 29,1 & 38,5 & 61,1 & $30-50$ \\
\hline
\end{tabular}

Zdroj: Výročné správy ČPP za roky 2005 - 2010; Výročná správa ČAP za rok 2010 a vlastné výpočty.

Ukazovatel' TR/likvidné prostriedky by nemal prekročit' hranicu $100 \%$. ČPP v sledovanom období splnila kritériá ratingovej agentúry a rok 2010 ukončila hodnotou 75,3\%. Podobnú vykazuje v danom roku aj celé odvetvie $(76,5 \%)$. Môžeme tak konštatovat', že poist'ovňa i celý trh majú dostatok likvidných prostriedkov na krytie prípadných záväzkov.

Podiel záväzkov na likvidných prostriedkoch zaznamenáva v ČPP v období rokov 2004 až 2007 klesajúci trend, na ktorom sa podiel'ali predovšetkým dosiahnuté hodnoty za prvý rok. Vtedy došlo k navýšeniu likvidných aktív a súčasne k poklesu záväzkov na tretinovú úroveň. V súčasnosti poist'ovňa s hodnotou $4 \%$ vykazuje lepšiu schopnost' splácania záväzkov ako celé české poistné odvetvie $(5,6 \%)$.

Ukazovatel' solvency ratio je podrobne interpretovaný v predchádzajúcej podkapitole, pričom práve oblast' solventnosti bola najkritickejšou pre ČPP. Poist'ovňa je vysoko likvidná, ale predovšetkým v minulosti mala zároveň problémy so solventnost'ou z dôvodu nízkeho objemu vlastných zdrojov.

\subsection{Analýza rentability}

Najdôležitejšími ukazovatel'mi rentability sú ROA (rentabilita celkových aktív) a ROE (rentabilita vlastného kapitálu). Vývoj ukazovatel'ov rentability v ČPP za obdobie 2005 až 2010 a hodnoty českého poistného odvetvia (zastúpeného členmi ČAP) v roku 2010 znázorňuje Tabul'ka č. 4.

Tabul'ka č. 4 Vývoj ukazovatel'ov rentability

\begin{tabular}{|c|r|r|r|r|r|r|r|c|}
\hline Ukazovatele (v \%) & $\mathbf{2 0 0 5}$ & $\mathbf{2 0 0 6}$ & $\mathbf{2 0 0 7}$ & $\mathbf{2 0 0 8}$ & $\mathbf{2 0 0 9}$ & $\mathbf{2 0 1 0}$ & ČR 10 & S \& P \\
\hline ROA & 0,21 & 1,60 & 2,01 & 3,37 & 3,55 & 3,21 & 4,90 & neuvádza \\
\hline ROE & 1,33 & 11,46 & 16,21 & 21,76 & 21,45 & 18,42 & 26,05 & $>5$ \\
\hline
\end{tabular}

Zdroj: Výročné správy ČPP za roky 2005 - 2010; Výročná správa ČAP za rok 2010 a vlastné výpočty. 
Rentabilita celkových aktív (ROA) má od vstupu kapitálu skupiny VIG (rok 2005) s výnimkou posledného sledovaného roku rastúci charakter a to až na 3,6 \% v roku 2009, ale v poslednom roku sa ROA znížila na 3,2\%. To znamená, že na 100 Kč celkových aktív pripadajú 3,2 Kč čistého zisku. Poist'ovňa v posledných dvoch rokoch vykazuje nižšiu efektívnost' zhodnotenia majetku ako celý český poistný trh (3,9 a 4,9\%).

Rentabilita vlastného kapitálu (ROE) má rastúci trend od vstupu poist’ovne do VIG až do roku 2008, kedy bola ROE 21,8 \%. V samotnom roku vstupu poist'ovne do rakúskeho koncernu však ROE zaznamenalo najnižšiu hodnotu (len 1,3\%), čo bolo spôsobené jednak poklesom zisku, ale predovšetkým prílevom kapitálu nového akcionára. Zhodnotenie vlastného imania v roku 2010 činilo 18,4\%. Každých 100 Kč vloženého vlastného kapitálu teda vyprodukovalo takmer 18,4 Kč disponibilného zisku. Poistný trh v ČR zaznamenal zhodnotenie až 26,1 \%. Vyššiu ROE ako české poistné odvetvie zaznamenala ČPP len v roku 2008 a s vel'mi malým rozdielom aj v roku 2009.

\subsection{Analýza investičnej činnosti}

Celkové investície v poist’ovni majú rastúci charakter a zaznamenávajú vel'ké medziročné nárasty. Tie v prvých troch sledovaných rokoch vždy prekročili $50 \%$ a v roku 2005 predstavoval medziročný nárast až takmer $80 \%$. Od tohto roku však tempo rastu investícií činilo 14 až $29 \%$ a v poslednom roku to bolo len $8 \%$. Aj v tomto roku však výrazne prevyšovalo rast celého českého poistného trhu, ktorý predstavoval $3 \%$. ČPP tak v súčasnosti eviduje finančné aktíva v hodnote 9714 mil. Kč. Štruktúru investícií ČPP za roky 2005 2010 a českého poistného trhu (členovia ČAP) v roku 2010 obsahuje Tabul'ka č. 5.

Tabul'ka č. 5 Vývoj štruktúry investičného portfólia ČPP za roky 2005 až 2010 a ČR v roku 2010 (bez finančného umiestnenia v mene poistených)

\begin{tabular}{|l|c|c|r|r|r|r|r|r|}
\hline & M. j. & $\mathbf{2 0 0 5}$ & $\mathbf{2 0 0 6}$ & $\mathbf{2 0 0 7}$ & $\mathbf{2 0 0 8}$ & $\mathbf{2 0 0 9}$ & $\mathbf{2 0 1 0}$ & \multicolumn{1}{c}{$\mathbf{\text { C 10 }}$} \\
\hline Dlhové CP & mil. Kč & 2484 & 4584 & 6033 & 7374 & 8533 & 9005 & 260179 \\
\hline Bankové vklady & mil. Kč & 1887 & 935 & 338 & 338 & 232 & 306 & 26978 \\
\hline $\begin{array}{l}\text { Akcie a CP s } \\
\text { premenlivým výnosom }\end{array}$ & mil. Kč & 43 & 175 & 239 & 212 & 232 & 395 & 21067 \\
\hline Nehnutel'nosti & mil. Kč & 0 & 0 & 0 & 7 & 7 & 7 & 4709 \\
\hline Majetkové účasti & mil. Kč & 0 & 0 & 0 & 0 & 0 & 0 & 13180 \\
\hline Ostatné & mil. Kč & 1 & 0 & 0 & 0 & 0 & 1 & 2707 \\
\hline Investície spolu & mil. Kč & $\mathbf{4 4 1 5}$ & $\mathbf{5 6 9 5}$ & $\mathbf{6 6 1 0}$ & $\mathbf{7 9 3 1}$ & $\mathbf{9 0 0 5}$ & $\mathbf{9 7 1 4}$ & $\mathbf{3 2 8 ~ 8 2 0}$ \\
\hline Nárast investícií & $\%$ & 79,44 & 28,98 & 16,07 & 19,99 & 13,54 & 7,88 & 3,07 \\
\hline
\end{tabular}

Zdroj: Výročné správy ČPP za roky 2005 - 2010; Výročná správa ČAP za rok 2010 a vlastné výpočty.

Poist'ovňa investuje konzervatívne a nedodržiava dostatočne zásadu diverzifikácie vzhl'adom na typ finančných aktív. Potvrdzuje to vel'ký podiel dlhových cenných papierov a bankových vkladov (pred rokom 2006), zároveň žiadne prípadne takmer žiadne nehnutel'nosti, či majetkové účasti, úvery a pôžičky. Z analýzy vývoja investícií ČPP možno usúdit', že výrazne dominantné postavenie finančného umiestnenia tvoria dlhové cenné papiere. Práve tieto aktíva prinášajú poist’ovniam najvyššie zhodnotenie. Objem i podiel dlhových CP má rastúcu tendenciu (s výnimkou podielu v poslednom roku) a v roku 2009 predstavoval ich podiel až 94,8 \% (92,7 \% v poslednom roku). Pozitívny klesajúci trend zaznamenávali termínované vklady, ked' pred rokom 2006 tvorili vyše $40 \%$ investícií, ale v roku 2009 už len 2,6\%. $\mathrm{V}$ poslednom roku sa ich podiel mierne zvýšil na 3,2\%. Cenné papiere s premenlivým 
výnosom majú nízky podiel a v roku 2009 tvorili len 2,6 \% finančných aktív. Medziročne sa ich podiel zvýšil o 1,5 \% na súčasných 4,1\%. Graf č. 2 zobrazuje štruktúru investičného portfólia ČPP a českého poistného trhu (zastúpeného členmi ČAP) v roku 2010.

Graf č. 2 Štruktúra investičného portfólia ČPP a poistného trhu v ČR v roku 2010

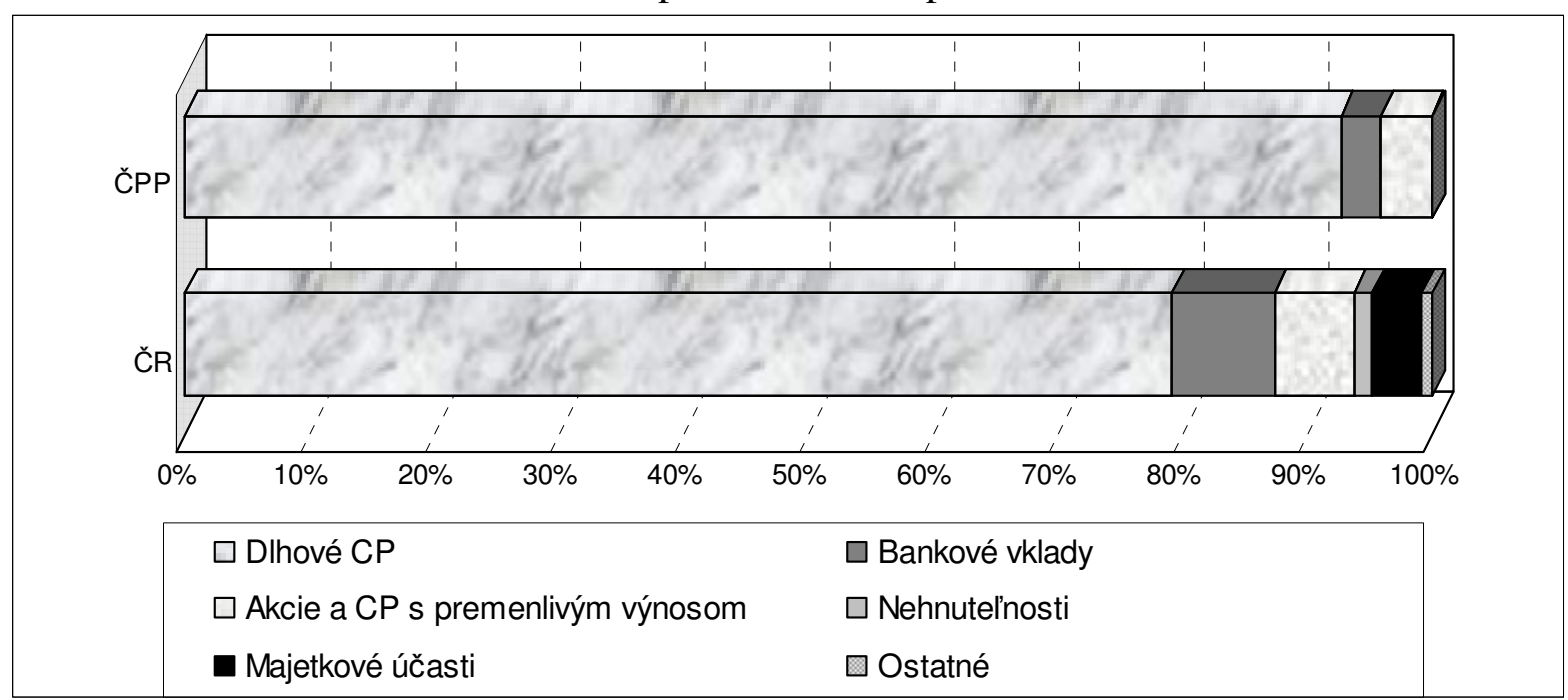

Zdroj: Výročná správa ČPP za rok 2010 a Výročná správa ČAP za rok 2010.

\section{Záver}

Česká podnikatelská pojišt'ovna, a. s., Vienna Insurance Group dosiahla rôznorodé výsledky pri hodnotení jej finančného zdravia. Zhodnotenie finančnej situácie poist'ovatel'a sme realizovali prostredníctvom ukazovatel'ov, ktoré využíva renomovaná ratingová agentúra Standard \& Poor's pri udel'ovaní poist'ovacích ratingov.

Výborné výsledky dosiahla poist'ovňa $\mathrm{v}$ náraste predpísaného poistného, ked' v hodnotenom období zaznamenala väčšinou vyššie nárasty ako odvetvie poist'ovníctva v ČR a s výnimkou roku 2003 zároveň spíňala odporúčané hodnoty ratingovej agentúry $(-10$ až $+30 \%)$. Akcionár kladie dôraz na návratnost' prostriedkov, čo vyplýva z rastúceho trendu hodnôt ROA a ROE od vstupu poist'ovne do koncernu VIG v roku 2005. Napriek medziročnému poklesu týchto ukazovatel'ov v poslednom sledovanom roku zaznamenal poist'ovatel' v oblasti rentability výborné výsledky. Najväčší problém poist’ovatel'a predstavoval nízky objem vlastného kapitálu, čo mohlo ohrozit' solventnost' spoločnosti. Poist'ovňa sa však dokázala dostat' z nepriaznivých hodnôt a zaznamenala pozitívny vývoj v oblasti solventnosti a zadlženosti. Druhým identifikovaným negatívom je nedostatočná diverzifikácia investičného portfólia. Poist'ovňa investuje konzervatívne, čoho dôkazom je až 93 \%-ný podiel dlhových cenných papierov na investíciách. Pozitívne hodnotíme vývoj finančnej situácie poist'ovne v sledovanom období.

Roky 2008 a 2009 boli pre poist'ovňu rizikové, pretože vplyv hospodárskej krízy a nedostatok vlastného kapitálu mohli ohrozit' solventnost' spoločnosti. Namiesto týchto obáv však poist'ovatel' zaznamenal vel'mi úspešné roky svojej existencie a vo výborných výsledkoch pokračoval aj v roku 2010. Na základe všetkých týchto skutočností hodnotíme poist’ovňu ako finančne stabilnú. 


\section{Literatúra:}

[1] ALTEMÖLLER, F.: European Merger Controls in Liberalized and Deregulated Insurance Markets: The Decision - Making Practice of the European Commission and the Future Outlook for the Delineation of the Market. In: The Geneva Papers on Risk and Insurance, July 2000, Vol. 25, No. 3, 369 - 395.

[2] KAFKOVÁ, E., RADVANSKÁ, K., PEKÁRIKOVÁ, E.: O analizie finansowej podmiotów zaleznych Grupy Allianz z siedzibami w Slowaci, Czechach i na Wegrzech. In: Rozwój rynków ubezpieczeń w krajach Europy Środkowej i Wschodniej, Kraków, 2. - 4. 10. 2003 s. 309 - 322. ISBN 83-7252-179-4.

[3] LUKÁČ, M.: Zhodnotenie finančnej situácie vybraných poist'ovní skupiny Vienna Insurance Group (Diplomová práca). Košice : PHF EU, 2009, 111 s.

[4] MAJTÁNOVÁ, A.: Systém poistných vzt'ahov v národnom hospodárstve. In Národohospodářský obzor. Brno - Karviná : ESF MU, OPF SU. 2002, č. 4, s. 51 - 66. ISBN 1213-2446.

[5] PASTORÁKOVÁ, E.: Javové podoby globalizácie na poistnom trhu v Slovenskej republike. In: Ekonomický časopis č. 8/54/2006, s. 785-802. ISSN 0013-3035.

[6] REJDA, G. E.: Principles of Risk Management and Insurance. Addison Wesley. International Edition. Ninth Edition, 2005. 345678910-CRW-08070605.

[7] European Insurance in figures, August 2007 CEA.

[8] Výročné správy ČAP, roky 2003 - 2010.

[9] Výročné správy ČPP, roky 2003 - 2010.

[10] Výsledky členov ČAP, roky 2005 - 2009.

[11] http://www.cpp.cz/ (2011-09-14).

[12] http://www.standardandpoors.com/ (2009-01-26).

\section{Klasifikácia JEL: G22}

\section{Ing. Miroslav Lukáč}

Katedra financií a účtovníctva

Podnikovohospodárska fakulta EU v Bratislave

so sídlom v Košiciach

Tajovského 13, 04130 Košice

miroslav.lukac@euke.sk

\section{doc. Ing. Eva Kafková, PhD.}

Katedra ekonómie

Podnikovohospodárska fakulta EU v Bratislave

so sídlom v Košiciach

Tajovského 13, 04130 Košice

eva.kafkova@euke.sk 